\title{
RESÚMENES DE LAS CONFERENCIAS
}

\section{MISCELÁNEOS}

\section{Casos clínicos}

\section{Testosterona en pacientes con cáncer de próstata}

\section{Dr. César Augusto González Encinales}

Médico Cirujano, Especialista en Urología y Andrología Profesor Asociado de Posgrado de la Universidad Militar Nueva Granada, la FUCS, La Universidad del Bosque y la Universidad Colsanitas. Jefe del Servicio de Urología y Andrología del Hospital Central de la Policía Nacional de Colombia, y Director Científico de ANDROFERTIL, Bogotá.

$\mathrm{E}$ n 1941, Huggins y Hodges demostraron que la disminución de Testosterona por castración causaba en el cáncer de próstata metastásico una regresión y que la administración de testosterona exógena favorecía el desarrollo del cáncer.

En la actualidad sabemos que no hay una clara correlación entre incremento de la testosterona y aumento en la incidencia de cáncer de próstata.

Por otro lado los niveles de andrógenos disponibles no son los únicos factores que influencian la aparición y progresión del cáncer de próstata.
La incidencia de hipogonadismo en el paciente con cáncer de próstata puede ser la misma o aun mayor a la observada en la población general, encontrándose que hasta en un 15\% de hombres hipogonádicos con PSA menor o igual a 4, se podrían obtener biopsias positivas, implicando esto que la presencia de cáncer de próstata podría estar en una tasa similar a la encontrada en pruebas de screening de cáncer para hombres con PSA con valores menores a 4,0 ng/dl.

Por todo lo anterior es muy importante poder conocer como diagnosticar, tratar y seguir adecuadamente y con objetividad a un gran número de pacientes con hipogonadismo y cáncer de próstata previamente tratados, bien sea con vigilancia activa, prostatectomía radical, radioterapia y braquiterapia, mediante la revisión y aplicación de protocolos y guías de manejo, que nos permitan ofrecer una mejor calidad de vida a esta población especial de pacientes.

\section{Bloque Simposio - Salud Masculina Current concepts for treating male hypogonadism}

\section{Eberhard Nieschlag}

Center for Reproductive Medicine and Andrology

University Hospital of Münster, Germany

48129 Münster / Germany

Email address: Eberhard.nieschlag@ukmuenster.de

www.nieschlag.de

$\mathrm{H}$ ypogonadism is defined as impaired testicular function in which either the endocrine of the exocrine or both may be affected, leading to deficient androgenicity and/or infertility. Eventually, all forms of endocrine hypogonadism require testosterone substitution. As principles of testosterone therapy have been discussed in my previous lecture on late-onset hypogonadism and the time frame is restricted this topic will not be discussed here again.

Only in cases of secondary/central (= hypogonadotropic) hypogonadism, when paternity is requested, a stimulatory therapy with gonadotropins (LH/hCG plus FSH) or pulsatile GnRH may be temporarily indicated. Pulsatile GnRH is reserved for central hypogonadism caused by GnRH deficiency such as Kallmann syndrome and congenital hypogonadotropic hypogonadism ( $\mathrm{CHH}$ ) while gonadotropins can be used in all forms of secondary hypogonadism. The previously used urinary gonadotropin preparations have more recently been replaced by recombinant hCG and FSH. Depending on the underlying cause of $\mathrm{HH}$ and the initial testicular volume stimulation therapy may take up to 2 years or even longer until sufficient sperm are produced to induce pregnancies either spontaneously or by assisted reproductive techniques (ART).

In cases where indicated, it remains undecided whether GnRH or gonadotropins are more efficient in inducing testosterone production and fertility. However, both modalities have disadvantages as pulsatile GnRH treatment requires constant 
wearing of a pump and gonadotropin therapy requires frequent injections. Due to the half-life of the gonadotropins hCG needs to be injected twice a week and FSH even three times a week. A longer-acting recombinant FSH preparation (consisting of the FSH $\alpha$-subunit and a hybrid of the FSH $\beta$-subunit and part of the hCG $\beta$-subunit) is currently under investigation for hypogonadotropic hypogonadism. This preparation needs to be injected only every 2 weeks and will make therapy more convenient.

In the adult men stimulation therapy should be initiated as soon as the diagnosis has been established, even if paternity is not immediately required, because this initial treatment will show whether spermatogenesis can be sufficiently stimulated and experience shows that a second course of treatment even years later will stimulate spermatogenesis faster than a first course. Cryopreservation of sperm may also be considered for later use without the need of renewed stimulation therapy. Once sufficient sperm for paternity have been produced testosterone substitution will be initiated or resumed as longterm therapy.

In adolescent boys with constitutional delay of puberty a short-term testosterone stimulation is generally accepted for induction of pubertal development. Testosterone should not be over-dosed in order not to compromise final adult height by premature epiphyseal closure. Controversy exists in regard to congenital forms of secondary hypogonadism. While induction of pubertal development by testosterone is used in most cases, recent studies show that stimulation by hCG and FSH not only induces androgenicity but also testicular growth and spermatogenesis providing the patient with increased quality of life and self-esteem. Once sufficient testicular growth has been achieved, therapy can continue with testosterone substitution.

In infertile men testosterone treatment is generally counterproductive as it suppresses gonadotropins and spermatogenesis and would thus further compromise fertility. However, in a subset of obese infertile men suffering from a mild form of secondary hypogonadism instead or prescribing testosterone they may benefit from administration of enclomiphene stimulating LH and testosterone secretion as well as increasing sperm counts. However, it remains to be determined whether pregnancy rates will also increase.

Until recently men with Klinefelter syndrome, the most common form of primary hypogonadism, were considered infertile as about $90 \%$ of them are azoospermic and the remaining may produce only a few sperm insufficient to induce a pregnancy naturally. Recently sperm were obtained by testicular sperm extraction (TESE) for intracytoplasmic sperm injection (ICSI) into oocytes resulting in life-born children. Most of these children have a euploid karyotype as these sperm derive from tubuli with euploid spermatogonial foci. As shown in a Klinefelter mouse model these spermatogonia get lost during early development so that cryopreservation of testicular biopsies from prepubertal boys for later gamete maturation in vitro is performed on an experimental basis. However, it is too early to recommend this approach as general practice. Nevertheless, as testosterone suppresses spermatogenesis in adolescent and adult Klinefelter patients fertility aspects should be discussed before testosterone therapy is initiated or a long testosterone washout period has to be implemented before testicular biopsy.

\section{Suggested further reading}

1. Nieschlag E, Behre HM, Nieschlag S (eds.). Testosterone: Action, deficiency, substitution. 4th edition, Cambridge University Press, Cambridge, 2012

2. Nieschlag E, Ferlin A, Gravholt CH, Gromoll J, Köhler B, Lejeune H, Rogol AD, Wistuba J. The Klinefelter Syndrome Round Table Discussion. Andrology 2015;4: 545-549.

3. Nieschlag E, Bouloux P-MG, Stegmann BJ, Shankar RR, Guan Y, Tzontcheva A, McCrary Sisk C, Behre H. Efficacy and safety of the long-acting Corifollitropin Alfa in combination with hCG in adult men with hypogonadotropic hypodonadism. Reprod Biol Endocrinol 2017;15:17. doi: 10.1186/s12958-017-0232-y.
4. Rohayem J, Hauffa BP, Zacharin M, Kliesch S, Zitzmann M and the German Adolescent Hypogonadotropic Hypogonadism Study Group (incld. Nieschlag E). Testicular growth and spermatogenesis: new goals for pubertal hormone repleacement in boys with hypogonadotropic hypogonadism? a multicenter prospective study of $\mathrm{hCG} / \mathrm{rFSH}$ treatment outcomes during adolescence. Clin Endocrinol 2017;86:75-87.

5. Rohayem J, Nieschlag E. Stimulation of spermatogenesis in hypogonadotropic men. In : Male hypogonadism : Basic, Clinical and Therapeutic Principles. Winters Huhtaniemi (eds.) (2nd) Springer 2017.

\section{Conferencia Magistral}

\section{Testosterone substitution in the aging male: when and how?}

\section{Eberhard Nieschlag}

Center for Reproductive Medicine and Andrology

University Hospital of Münster, Germany

48129 Münster / Germany

Email address: Eberhard.nieschlag@ukmuenster.de

www.nieschlag.de
$\mathrm{H}$ ypogonadism is the most frequent endocrinopathy among males, but remains often overlooked and untreated. This happens despite the fact that symptoms of testosterone deficiency are easily recognized, both clinically and biochemically. Aside from the classic primary and secondary (or central) forms of hypogonadism, today, in view of 
increasing lifespan and the rising expectations of the quality of life, late onset hypogonadism ( $\mathrm{LOH}$ ), a mix of primary and secondary hypogonadism, plays an ever increasing role in the physicians' daily practice.

Male aging may be accompanied by many symptoms such as decreased physical and mental activity, loss of libido and erectile function, low cognitive functions, depressive mood, increased fat mass (especially abdominal), metabolic syndrome, diabetes type 2, sarcopenia, osteoporosis and anemia. These symptoms are uncharacteristic and may be caused by other diseases, but these diseases can also be caused by LOH. Therefore, patients with these symptoms need a careful diagnostic work-up and only when symptoms are accompanied by low serum testosterone the diagnosis $\mathrm{LOH}$ can be considered. The incidence of true LOH is estimated to range between 2 and $5 \%$ of men over 65 .

Any prescription of testosterone without the pre-condition of symptoms plus low testosterone must be considered as malpractice. However, there is controversy about the threshold levels when to initiate testosterone substitution. This is partially caused by the fact that the various symptoms of testosterone deficiency show different threshold levels. In Germany, levels below normal testosterone levels in younger men i.e. $12 \mathrm{nmol} / \mathrm{L}$ are accepted as indication for substitution.
In addition to a multitude of earlier studies 9 US academic centers recently performed 7 trials to clarify the effects of testosterone in $\mathrm{LOH}$ which demonstrate beneficial effects of testosterone sexual function, osteoporosis and anemia. Treatment limited to one year may not have been long enough to establish further benefits. Other recent studies have concluded that testosterone substitution in $\mathrm{LOH}$ is beneficial for obesity, metabolic syndrome, diabetes type 2, cardiovascular diseases while effects on cognitive functions remain controversial.

Of the 3 testosterone preparations available in Colombia transdermal testosterone gel may be best suited for $\mathrm{LOH}$ treatment, especially in the first year of substitution. Since testosterone enanthate produces supraphysiological testosterone levels, the 3-months depot of testosterone undecanoate might be considered for the long-term substitution of $\mathrm{LOH}$, provided the patient is carefully monitored at regular intervals for red blood (to avoid polycythemia), for prostate size and PSA and occasional serum testosterone levels before the next dose application. Bone mineral density should be measured in 2 yearly intervals. Large epidemiologic studies have demonstrated that testosterone substitution does not increase the incidence of prostate carcinoma.

\section{Suggested further reading:}

1. Debruyne FM, Behre HM, Roehrborn CG et al. Testosterone treatment is not associated with increased risk of prostate cancer or worsening of lower urinary tract symptoms: prostate health outcomes in the Registry of Hypogonadism in Men. BJU Int. 2017;119:216-224.

2. Nieschlag E, Behre HM, Nieschlag S (eds.) Testosterone: Action, deficiency, substitution. 4th edition, Cambridge University Press, Cambridge, 2012.

4. Nieschlag E. Current topics in testosterone replacement of hypogonadal men. Best Practice \& Research Clinical Endocrinology \& Metabolism 29: 77 90, 2015.

5. Snyder PJ, Ellenberg SS, Cunningham GR et al. The Testosterone Trials: Seven coordinated trials oftestosterone treatment in elderly men. Clin Trials.
2014;11:362-375.

6. Traish AM, Haider A, Doros G, Saad F. Long-term testosterone therapy improves cardiometabolic function and reduces risk of cardiovascular disese in men with hypogonadism: a real-life observational registry study setting comparing treated and untreated (control) groups. J Cardiovasc Pharmacol Therapeut 2017:22.

7. C. Wang, Nieschlag, E., R. Swerdloff, H. M. Behre, W.J. Hellstrom, L. J. Gooren J. M. Kaufman, J.-J Legros, B. Lunenfeld, :A. Morales, J. E. Morley, C. Schulman, I.M. Thompson, W. Weidner, F. C. W. Wu. Investigation, treatment and monitoring of late-onset hypogonadism in males: ISA, ISSAM, EAU, EAA and ASA recommendations. Eur J Endocrinol 15:507-514 (2008).

\section{Bloque Simposio - Paratiroides}

\section{Indicación para el tratamiento del hipoparatiroidismo} con PTH

\section{Henry Mauricio Arenas Quintero}

Endocrinólogo Universidad Nacional de Colombia. Densitometrista clínico ISCD

Miembro de Número ACE. Miembro ACOMM

Docente de cátedra posgrado de medicina interna, Universidad

Tecnológica de Pereira

$\mathrm{L}$ a hormona paratiroidea (PTH) es una de las principales reguladoras del metabolismo fosfocálcico del organismo, regula el calcio sérico por efectos directos en el hue- so y riñón y por efectos indirectos mediados por vitamina D en el intestino.

Se define hipoparatiroidismo a la producción de PTH insuficiente o nula para mantener niveles séricos adecuados de calcio y fósforo en el organismo.

\section{Etiología}

El hipoparatiroidismo puede ocurrir principalmente por destrucción autoinmune (síndrome poliglandular autoinmune 
tipo 1, por mutación en el gen AIRE), anticuerpos activadores del receptor sensor de calcio, alteración en el desarrollo de las glándulas paratiroides, enfermedades infiltrativas como hemocromatosis, enfermedad de Wilson, granulomas o metástasis, producción alterada o falta de acción de la PTH. Sin embargo, la causa más frecuente es por la intervención quirúrgica debido a cáncer de tiroides o de estructuras vecinas. El hipoparatiroidismo posterior a cirugía puede ser transitorio, con recuperación en días, semanas o meses, puede ser permanente o en ocasiones intermitente. El hipoparatiroidismo transitorio ocurre hasta en un $20 \%$ de los pacientes luego de cirugía para cáncer de tiroides y es permanente entre un $0,8 \%$ y un $3 \%$ de los pacientes a los que se les ha realizado tiroidectomía total.

Las manifestaciones clínicas de la hipocalcemia se localizan en un espectro que va desde sintomatología mínima hasta tetanización, falla cardiaca, laringoespasmo y convulsiones. El signo cardinal es la tetanización signo de Chvostek y signo de Trosseau, irritabilidad neuromuscular, los síntomas más frecuentemente reportados son parestesias periorales, parestesias palmoplantares y calambres. Algunos pacientes tienen síntomas menos específicos, como adinamia, ansiedad, depresión, irritabilidad, hipotensión, prolongación del intervalo QT, arritmia y falla cardiaca. Cuando la hipocalcemia por hipoparatiroidismo es crónica se observan calcificaciones de los ganglios basales, cataratas, anomalías dentales y manifestaciones ectodérmicas.

En los hipoparatiroidismos congénitos se observa osteoesclerosis, engrosamiento de la cortical ósea y anormalidades craneofaciales.

En pacientes con síndrome poliglandular autoinmune tipo 1 se observa candidiasis, con compromiso de uñas, piel y tracto gastrointestinal.

\section{Hallazgos paraclínicos}

- Hipocalcemia con PTH baja o inapropiadamente normal

- Hiperfosfatemia

- 25 hidroxivitamina D (250HD) normal

- 1,25 dihidroxivitamina D (1,25D) baja

- Hipercalciuria

- Hipofosfaturia

- Magnesio normal

- Creatinina normal

\section{Diagnóstico}

La hipocalcemia persistente con una PTH baja o inapropiadamente normal, con hiperfosfatemia en ausencia de hipomagnesemia, nos da el diagnóstico de hipoparatiroidismo.
Estos hallazgos pueden darse en pacientes sintomáticos o en ocasiones asintomáticos.

El diagnóstico se confirma con la medición simultánea de calcio sérico total, albúmina, magnesio, PTH intacta. El calcio ionizado se solicita en pacientes con enfermedad renal crónica o en sospecha de hipoalbuminemia como en los pacientes con falla hepática.

En pacientes con antecedentes familiares, o que hayan presentado en alguna ocasión hipocalcemia, debe ampliarse el estudio de hipoparatiroidismo, pues muchos son asintomáticos y pueden desarrollar complicaciones a largo plazo, especialmente sintomatología neurológica.

\section{Diagnóstico diferencial}

- Hipomagnesemia

- Mutación del receptor sensor de Calcio

- Hipocalcemia autosómica dominante

\section{Evaluación y tratamiento}

Se debe estar seguro de los niveles de magnesio y niveles de calcio urinario antes del inicio del tratamiento, excepto si este amenaza la vida.

Si el paciente tiene hipocalcemia aguda y severa (p. ej. convulsiones, laringoespasmo, falla cardiaca) se inicia gluconato de calcio intravenoso 1 a 2 g para pasar en 15 a 20 minutos y luego continuar con infusión de 0,5 a 1,5 mg/kg/h, vigilando estrechamente con niveles séricos. Para preparar la infusión se adicionan 5 ampollas de gluconato de calcio en 450 cc de DAD 5\%.

Debe iniciarse simultáneamente, si es posible, calcitriol y suplementación oral de carbonato de calcio o citrato en pacientes con aclorhidria.

En pacientes con hipocalcemia por hipoparatiroidismo crónico se debe asegurar la ingesta de calcio elemental y calcitriol para mantener unos niveles séricos de calcio total entre 8 y $8,5 \mathrm{mg} / \mathrm{dl}$ y prevenir hipercalciuria por el riesgo de urolitiasis y nefrocalcinosis.

Si hay hipercalciuria se recomienda disminuir la dosis de calcio, y si no es posible por síntomas, adicionar diurético tiazídico hidroclorotiazida 12,5 a 50 mg QD.

Si a pesar de una adecuada suplencia de calcio, uso de calcitriol y diurético tiazídico no se logra un adecuado control o hay desarrollo de complicaciones, está indicada la sustitución con PTH 1-84, iniciando con dosis desde 50 mcg SC diario. Esta se reserva por su elevado costo y la ausencia de estudios de seguridad a largo plazo para pacientes sintomáticos refractarios. 


\section{Conferencia Magistral}

\section{Continuing medical education, and how to do it}

\section{Leslie De Groot}

$\mathrm{T}$ raditional lecture-based approaches to undergraduate medical education have been superseded in medical schools to a major extent by "interactive education" and "Problem-based learning". Both teaching techniques are proven to be superior when assessed by short term retention. Little or no data, is available comparing long term retention, comparison of retention based on time commitment, or on use in practice. Some form of Continuing medical Education becomes vital after residency and for the remainder of a physicians productive work-span of 30-70 years. Reading the well organized summaries of endocrine diseases in THYROIDMANAGER.ORG and EDOTEXT.ORG offers one approach, but with limitations related to the "lecture" structure. Both websites consist of a comprehensive, text-book like format, with non-biased material written by experts from around the world, and are constantly updated, constantly available on the web for reading, and FREE.

\section{Conferencia Magistral}

\section{Transgender medicine - diagnosis \& management}

\section{Michael S. Irwig MD}

Associate Professor of Medicine, George Washington University, Washington DC

$\mathrm{T}$ ransgender communities exist across multiple countries and continents. However, the degree of awareness and acceptance of individuals with gender dysphoria varies widely. Over the past five years there has been a dramatic cultural shift in the United States and other countries such that many more transgender people are now open about their gender identities. In fact, one population study in Massachusetts estimates that 1 in 215 people $(0.5 \%)$ identify as transgender. ${ }^{1}$ Nonetheless, transgender people represent one of the most marginalized groups in society, including health care settings.

\section{Diagnosis}

Several organizations (i.e. the International Statistical Classification of Diseases and Related Health Problems and the Diagnostic and Statistical Manual of Mental Disorder) have developed diagnostic criteria for gender dysphoria which was formerly called gender identity disorder. The hallmark is a marked incongruence between one's experienced gender and primary and/or secondary sex characteristics. The binary concept of gender (either male or female) also does not represent all people. For example, gender queer or non-binary individuals see gender as a spectrum rather than simply male or female. What determines one's gender identity is not well understood but various studies point to several biological factors. Studies comparing identical and non-identical twins found a concordance of $39 \%$ among the identical twins versus $0 \%$ among same-sex fraternal twins ${ }^{(2)}$. Another study found that the size of an area in the brain (central subdivision of the bed nucleus of the stria terminalis) of transgender women (male-to-female) corresponded to that of non-transgender women rather than non-transgender men ${ }^{(3)}$.

\section{Mental health}

Transgender individuals face very high rates of unemployment, harassment, physical assaults and sexual violence related to their gender identity. It therefore is not surprising that coming to the realization of their gender identity often transpires over many years and is often associated with stress and mental health struggles. Meeting other transgender people on-line or at support group is a typical first step. Establishing care with a mental health professional with expertise in gender dysphoria is a very important part of their care given the high rates of depression and anxiety. In fact, some studies estimate a suicide attempt rate of around $41 \%$. Hormone therapy fortunately is associated with a reduction in gender dysphoria in both transgender men and women.

It is important for endocrinologists to develop a relationship of mutual trust with their transgender patients. This involves taking a careful social history and inquiring about a patient's childhood, relationships and support system or lack thereof. Taking a genuine interest in a person's life goes a long way to establish a healthy and productive doctor-patient relationship. 


\section{Hormone therapy}

Many, but not all, transgender adults pursue hormone therapy so that they can align their physical bodies with their experienced gender. In some countries the taking of hormones is often done outside of the supervision and advice of medical professionals. This practice carries increased risks as individuals are often not fully aware about the effects and potential risks of hormone therapy. For example, many transgender women have unrealistic expectations about breast growth and take very high doses of estrogen. The knowledge and experience of endocrinologists regarding hormonal therapies can be used to effectively treat transgender patients while seeking to minimize adverse events. In general, the overall goal of cross-sex hormone therapy is to achieve serum levels of testosterone and estradiol consistent with the patient's desired gender. Crosssex hormone therapy in both transgender men and women lowers rates of gender dysphoria, perceived stress, anxiety and depression. The majority of the effects of the hormonal changes begin within several months of initiating therapy.

For transgender men, testosterone therapy promotes an array of desired physical effects including increased facial and body hair, a deeper voice, increased lean mass and strength, less fat mass, increased sexual desire, cessation of menses, and clitoral enlargement. Common undesired effects or risks include acne, alopecia, lower HDL cholesterol and higher triglycerides.

For transgender women, estrogen and antiandrogen therapy promotes breast development, softer skin, less sebum and acne, an increase in fat mass, a decrease in lean muscle mass and less facial and body hair. Common undesired effects or risks include infertility, sexual concerns, and higher triglycerides. An uncommon adverse effect is venous thromboembolism due to high doses of estrogen.

Transgender patients on hormone therapy should have periodic blood tests to monitor levels of testosterone and estradiol, lipids, electrolytes and hematocrit. When and how often to screen for reproductive cancers (i.e. breast, cervical, prostate, etc) is unclear due to a lack of evidence-based data and lower rates of several cancers in transgender populations.

For more information on transgender care, the Endocrine Society has a clinical practice guideline from 2009 which is currently being revised ${ }^{(4)}$. The World Professional Association for Transgender Health (WPATH) also publishes its Standards of Care ${ }^{(5)}$.

\title{
References
}

1. Conron KJ, Scott G, Stowell GS, Landers SJ. Transgender health in Massachusetts: results from a household probability sample of adults. Am J Public Health. 2012;102:118-122.

2. Heylens G, De Cuypere G, Zucker KJ, et al. Gender identity disorder in twins: a review of the case report literature. J Sex Med. 2012;9:751-757.

3. Zhou JN, Hofman MA, Gooren LJ, Swaab DF. A sex difference in the human brain and its relation to transsexuality. Nature. 1995;378:68-70.

4. Hembree WC, Cohen-Kettenis P, Delemarre-van de Waal HA, et al. Endocrine treatment of transsexual persons: an Endocrine Society clinical practice guideline. J Clin Endocrinol Metab. 2009;94:3132-54.

5. Coleman E, Bockting W, Botzer M, et al. Standards of Care for the Health of Transsexual, Transgender, and Gender-Nonconforming People. International Journal of Transgenderism, 2011;13:165-232.

\section{Bloque Simposio - Tumores Neuroendocrinos} Tumores neuroendocrinos funcionales pancreáticos: insulinoma

\author{
Diva Cristina Castro Martínez
}

Médica Internista, Endocrinóloga. Miembro de Número de la Asociación Colombiana de Endocrinología, Diabetes y Metabolismo, Envigado.

$\mathrm{L}$ os tumores neuroendocrinos se originan en las células del sistema neuroendocrino difuso, son tumores infrecuentes, el $61 \%$ son gastroenteropancreáticos y en el páncreas se ubica el 7\% de ellos. Los tumores neuroendocrinos de páncreas (PNET) pueden ser funcionales con produc- ción de: insulina, somatostatina, gastrina, glucagón, péptido intestinal vasoactivo, o pueden ser no funcionales ${ }^{(1)}$.

El insulinoma es el PNET más frecuente aunque tiene una incidencia de 4 casos por 1'000.000 de habitantes por año ${ }^{(2)}$. Se presenta con mayor frecuencia en mujeres (59\%), generalmente entre la cuarta y quinta década de la vida. Se presenta en forma esporádica en la mayoría de los casos y se asocia a neoplasia endocrina múltiple tipo 1 (NEM1) en $4 \%$ a $8 \%$ de los casos. Su manifestación clínica con hipoglucemia hiperinsulinémica genera importante morbilidad y 
usualmente es detectado con tamaño $<2 \mathrm{~cm}$ y localizado en páncreas; sin embargo presenta metástasis entre 5\% y 15\% (comportamiento maligno) ${ }^{(1)}$.

La producción tumoral de insulina es mayor a la de las células beta normales y al superar la respuesta contrarreguladora ocasiona hipoglucemia, más frecuentemente en ayuno 73\%, en ayuno y posprandial $21 \%$ y solo posprandial $6 \%{ }^{(2)}$.

\section{Manifestaciones clínicas}

La manifestación principal es hipoglucemia que se presenta en ayunas (73\%), posprandial (6\%) o mixta (21\%). Los síntomas hipoglucémicos son autonómicos adrenérgicos: palpitaciones, temblor y ansiedad, o colinérgicos: diaforesis, hambre y parestesias. Si la hipoglucemia se profundiza más aparecen los síntomas neuroglucopénicos: cefalea, confusión a amnesia, visión borrosa, diplopía, disartria, pérdida de la conciencia y, en casos graves, convulsiones o $\operatorname{coma}^{(3)}$. La hipoglucemia prolongada puede causar muerte cerebral e incremento de mortalidad en pacientes cardiópatas. En formas crónicas se presentan signos de resistencia a la insulina e incremento en la mortalidad.

\section{Diagnóstico}

Confirmar la presentación de la triada de Whipple (hipoglucemia demostrada, síntomas neuroglucopénicos y resolución de los síntomas con normalización de la glucemia) es el punto de partida para el estudio diagnóstico. La evaluación clínica permite descartar otras causas de hipoglucemia como: insuficiencia renal, hepática o cardiaca, sepsis, insuficiencia adrenal, hipopituitarismo, medicamentos (insulina, secretagogos de insulina, pentamida, quinina, propanolol, haloperidol, salicilatos, sulfonamidas, alcohol) y origen tumoral (hepatoma, cáncer gástrico y sarcomas productores de IGF-II) $^{(2,3)}$.

Para demostrar hipoglucemia-hiperinsulinemia se requiere medir: glucemia central, niveles de insulina, proinsulina, péptido $C$, cuerpos cetónicos ( $\beta$-hidroxibutirato si está disponible), niveles de sulfonilureas. La medición se puede realizar en hipoglucemia espontánea, durante test de ayuno de 72 horas o con test de comida mixta si presenta hipoglucemia posprandial ${ }^{(3)}$. Los niveles confirmatorios incluyen: glucemia $<55 \mathrm{mg} / \mathrm{dl}$, insulina $\geq 3 \mu \mathrm{U} / \mathrm{ml}$, péptido $\mathrm{C} \geq 0,2 \mathrm{nmol} / \mathrm{L}$, proinsulina de $\geq 5 \mathrm{pmol} / \mathrm{L}$, cuerpos cetónicos negativos. El péptido $\mathrm{C}$ y la proinsulina permiten descartar hiperinsulinemia exógena y los niveles negativos de sulfonilureas y de anticuerpos contra la insulina descartan consumo de hipoglucemiantes y autoinmunidad.

En presencia de hipoglucemia hiperinsulínica endógena, los diagnósticos diferenciales con insulinoma son: hipoglucemia pancreatógena no insulinoma (nesidioblastosis) e hipoglucemia pos bypass gástrico.
Con la confirmación bioquímica se inician los estudios de localización del tumor con métodos no invasivos o invasivos. Los estudios no invasivos incluyen: ecografía, tomografía computarizada, resonancia magnética, octreoscan y PET/CT. El rendimiento diagnóstico es bajo en los estudios no invasivos, con sensibilidad en: ecografía abdominal $<70 \%$, tomografía helicoidal multifase 40\%-94\%, resonancia magnética 71\%$95 \%$, octreoscan $57 \%$ (útil en identificación de metástasis). El PET18F-FDG tiene bajo rendimiento y el PET/CT Ga68 es positivo en 25\%-31\% de los $\operatorname{casos}^{(5)}$. El PET con análogos de GLP1 radiomarcados puede ser un método más sensible pero aún no está disponible.

Los métodos invasivos incluyen ecografía endoscópica + biopsia aspirado y la arteriografía selectiva con estimulación con calcio. La ecografía endoscópica es el método de elección inicial por tener un rendimiento diagnóstico de 80-100 en tumores ubicados en cabeza y cuerpo, en combinación con TAC tiene sensibilidad cercana a 100\%. La arteriografía con estimulación consiste en inyectar gluconato de calcio por un catéter en las arterias de circulación pancreática y medición de niveles de insulina en circulación venosa portal, tiene sensibilidad de 85\%-100\% sin embargo es un test complejo y de alto costo, por lo que se considera el método final de localización $^{(5)}$.

\section{Tratamiento}

El tratamiento de elección es la resección quirúrgica, el procedimiento depende del tamaño, localización y proximidad a estructuras anatómicas (ducto pancreático, vasos, órganos adyacentes), la enucleación es recomendada para tumores $<2$ $\mathrm{cm}$ y no cercanos al conducto pancreático ${ }^{(4)}$. En caso contrario se realiza resección segmentaria del páncreas (tumores en cuello o cuerpo) y pancreatectomía distal o pancreatoduodenectomía en tumores invasores con sospecha de malignidad o cercanos al conducto pancreático (riesgo de fístula). La cirugía laparoscópica se recomienda para enucleación o pancreatectomía distal y la cirugía abierta para resecciones más extensas. La ecografía intraoperatoria facilita la detección y delimitación del tumor con sensibilidad del $84 \%$ y combinada con palpación bimanual es cercana al 100\%(4,6).

Las complicaciones posquirúrgicas más frecuentes son: fístula, absceso intraabdominal (6,6\%), infección de herida quirúrgica $(2,5 \%)$, hemorragia $(1,3 \%)$ y pancreatitis $(0,6 \%)$; mientras que a largo plazo se presenta diabetes entre 5\%-60\% dependiendo de la extensión de la resección. La mortalidad es cercana a $0 \%$ al realizar enucleación, $1 \%$ - $2 \%$ en pancreatectomía izquierda y 4\%-5\% en pancreatoduodenectomía ${ }^{(6)}$.

Se requiere manejo médico preoperatorio de pacientes con hipoglucemia refractaria a dieta y $\mathrm{DAD}$, recidiva posoperatoria y sin posibilidad quirúrgica por: alto riesgo quirúrgico, enfermedad metastásica extensa o por negativa a la cirugía ${ }^{(2)}$. 
El medicamento de primera opción es diazóxido, con 200$600 \mathrm{mg} /$ día se controlan hasta 50\% las hipoglucemias. La siguiente opción es usar octreotide y lanreotide con control hasta $50 \%$ de los pacientes, se ha informado supresión de GH y glucagón con riesgo de empeorar la hipoglucemia. Se ha empleado everolimus solo y con octreotide en pacientes con insulinoma irresecable o metastásico ${ }^{(2)}$

\section{Pronóstico}

Luego de resección quirúrgica exitosa se tiene remisión completa a largo plazo en el 95\%. Se observa supervivencia a cinco años de $97 \%$ a cinco años y $88 \%$ a diez años; la recurrencia se presenta en 5\% a 10 años y 7\% a 20 años, con índices mayores en pacientes con MEN 1.

\section{Referencias}

1. Lawrence B, Gustafsson BI, Chan A, et al. The epidemiology of Gastroenteropancreatic Neuroendocrine tumors. Endocrinol Metab Clin N Am 40 (2011) 1-18.

2. Falconi M, Eriksson B, Kaltsas G, et al. ENETS Consensus Guidelines Update for the Management of patients with functional pancreatic neuroendocrine tumors and non-functional pancreatic neuroendocrine tumors. Neuroendocrinology 2016; 103: 153-171.

3. Cryer PE, Axelrod L, Grossman AB, et al. Evaluation and management of adult hypoglycemic disorders: an Endocrine Society Clinical Prac- tice Guideline. Journal of Clinical Endocrinology and Metabolism 2009; 94:709-28.

4. Placzkowski KA, Vella A, Thompson GB, et al. Secular trends in the presentation and management of functioning insulinoma at the Mayo Clinic, 19872007. Journal of Clinical Endocrinology and Metabolism 2009; 94:1069-73.

5. McAuley G, Delaney A, Colville J, Lyburn L. Multimodality Preoperative Imagining of pancreatic insulinomas. Clinical Radiology 2005; 60: 1039-150.

6. Mehrabi A, Fischer L, et al. A systematic review of localization, surgical treatment options, and outcome of insulinoma. Pancreas. 2014;43(5):675-686.

\section{Bloque Simposio - Transgénero Enfoque psiquiátrico del paciente transgénero}

\section{Dra. Juana Atuesta}

Médico Psiquiatra. Psiquiatra de niños y adolescentes. Jefe del Servicio de Psiquiatría Hospital de San José Docente de Psiquiatría Fundación Universitaria de Ciencias de la Salud FUCS

La transexualidad o disforia de género es un fenómeno que existe desde la antigüedad y en diferentes culturas. El término transexual se utiliza para denominar a los individuos que desean vivir de forma permanente como miembros del sexo opuesto y que desean someterse a la cirugía de reasignación de sexo, para manejar la incongruencia entre el sexo de nacimiento y el sexo al que se siente pertenecer. Dicho conflicto entre el sexo físico y el género psíquico produce en quien lo padece un "sentimiento intenso y doloroso de no pertenecer al sexo de nacimiento y pertenecer al sexo opuesto"; de ahí que el prefijo trans que indica "más allá", "fuera" o "después" se utilice para representar el movimiento entre uno y otro, no asimilable a las categorizaciones tradicionales estrictamente dicotómicas como masculino o femenino.

La transexualidad es un fenómeno cada vez más frecuente y visible en la práctica médica y en el funcionamiento social cotidiano, que muchas veces entra en conflicto con las concepcio- nes biológicas, psicólogicas, legales, religiosas, morales y culturales tradicionales, por lo que se requiere generar espacios de discusión que integren las humanidades, las ciencias sociales, el derecho y las ciencias biomédicas, entre otras, para garantizar una adecuada calidad de vida y la inclusión a la sociedad de los individuos que tienen esta condición, a través del respeto a su autonomía y dignidad como persona en su totalidad.

La transexualidad es uno de problemas bioéticos y médicos más vertiginosos existentes porque cuestionar las creencias preexistentes sobre la corporeidad, emocionalidad y la sexualidad, hace que sea fuente de dilemas complejos. Un intento por reducir dicha complejidad sería demostrar que la problemática de la transexualidad no es diferente a otros problemas sexuales, pudiéndose afirmar que no hay problema específico, excepto el de los prejuicios que históricamente han acompañado la sexualidad y las relaciones humanas. En este sentido, los conflictos que implica la transexualidad no serían cualitativamente diferentes a los relacionados con la heterosexualidad y la homosexualidad, pues la expresión de la sexualidad en cada una de ellas será el resultado de la interacción de la naturaleza biológica con las construcciones culturales de cada individuo. 